\title{
Detection of Hepatitis C Virus RNA in Saliva Is Not Related to Oral Health Status or Viral Load
}

\author{
Liliane Lins, ${ }^{1,3}$ Herbert Almeida, ${ }^{2}$ Ludmila Vitvisk, ${ }^{4}$ Theomira Carmo, ${ }^{1,2}$ Raymundo Paraná, ${ }^{2}$ \\ and Mitermayer G. Reis ${ }^{1,2,3 *}$ \\ ${ }^{1}$ Laboratório de Patologia e Biologia Molecular, Centro de Pesquisas Gonçalo Moniz, Fundação Oswaldo Cruz, Salvador, \\ Bahia, Brazil \\ ${ }^{2}$ Faculdade de Medicina, Universidade Federal da Bahia, Brazil \\ ${ }^{3}$ Escola Bahiana de Medicina e Saúde Pública, Salvador, Bahia, Brazil \\ ${ }^{4}$ INSERM U271, Lyon, France
}

\begin{abstract}
Hepatitis $\mathrm{C}$ is a worldwide public health problem and its transmission is clearly associated with the parenteral route, however, the virus has also been isolated from other body fluids. Hepatitis $C$ virus (HCV) RNA has been detected in saliva, yet the relationship between HCV and oral pathology is not clearly understood. Therefore, an investigation on HCV-RNA in saliva and its correlation with oral pathology was undertaken. Saliva and blood samples were collected from 50 antiHCV positive patients and from 25 patients with non-HCV chronic liver disease. HCV-RNA was detected in all of the saliva samples from the HCV positive group. None of the saliva or serum samples from the non-HCV group were positive for HCV-RNA. The patients were examined for dental and oral health (dentate, partially dentate, edentulous, evidence of gum disease, or mucosal lesions); however, no correlation was found between HCV-RNA in saliva, oral health, and viral load. These results suggest that HCV-RNA presence in saliva is independent of the viral load and the oral pathology of HCV positive individuals. J. Med. Virol. 77:216-220, 2005. ๑ 2005 Wiley-Liss, Inc.
\end{abstract}

KEY WORDS: hepatitis C; saliva; oral pathology

\section{INTRODUCTION}

Hepatitis $\mathrm{C}$ is estimated to have infected some 170 million people worldwide. In many countries, it is the most common cause of chronic liver disease as well as being the primary indication for liver transplantation in adults [Zekry et al., 2003]. Hepatitis $\mathrm{C}$ virus (HCV) is transmitted mainly by the parenteral route [Alter, 1996], however, in 30-40\% of cases, there is no history of blood transfusion or intravenous drug use [Allander et al., 1995]. Therefore, in order to assess non-parenteral routes of transmission, the detection of $\mathrm{HCV}$ in body fluids other than blood is of great importance. Seroepidemiological surveys indicate that saliva may be a potential source of infection, implying that dentists have an increased risk of exposure to HCV. However, the source of HCV in saliva has not been determined [Lodi and Porter, 1996]. The presence of HCV-RNA in saliva resulting from oral surgery has been evaluated [Chen et al., 1995]. Experimental infection by inoculation of HCV-contaminated saliva in non-human primates has been reported [Abe and Inchauspe, 1991], yet there are few reports of transmission by bite injuries in humans [Dusheiko et al., 1990; Figueiredo et al., 1994].

Saliva is composed of $90 \%$ water while the remainder consists of small amounts of other substances such as amylases, enzymes, thiocyanate, iodine, and IgA. Desquamated epithelial cells are the most common cellular components, other than bacteria that are found in saliva, although lymphocytes and polymorphonuclear leukocytes have also been identified. The presence of inflammatory cells in saliva is dependent on oral health, and elevated levels are thought to originate by the transudation of serum into the mouth via the gingival crevice. Studies have indicated that there is extensive HCV contamination of dental surgeries after treatment of anti-HCV positive patients. If sterilization and disinfection techniques are inadequate, there is an

Grant sponsor: Ministry of Health, Brazil; Grant number: Fiocruz-PDTIS 254461; Grant sponsor: Ministry of Science and Technology, Brazil; Grant number: FINEP/PRONEX 4196086200 (CNPq/INSERM and CAPES/CPOFECUB Cooperation Program, 304713/2002-3).

*Correspondence to: Mitermayer G. Reis, Centro de Pesquisa Gonçalo Moniz-FIOCRUZ, R. Waldemar Falcão, 121-Brotas, 40.295.001, Salvador, Bahia, Brazil.

E-mail: miter@cpqgm.fiocruz.br

Accepted 15 June 2005

DOI 10.1002/jmv.20438

Published online in Wiley InterScience

(www.interscience.wiley.com) 
increased risk of HCV transmission to exposed individuals [Chen et al., 1995; Piazza et al., 1995]. Some studies found an association between HCV infection and sialadenitis [Haddad et al., 1992; Jorgensen et al., 1996]; however, the correlation between periodontal disease and HCV in saliva is not well established [Maticic et al., 2001]. A number of epidemiological studies report an association between HCV in the saliva of patients with oral lichen planus [Bagan et al., 1998; Nagao et al., 1995], although this is not always the case [Tucker and Coulson, 1999].

The detection of HCV in saliva can be made indirectly by measuring antibody levels or by amplification of viral RNA. The efficacy of the detection of HCV antibodies in saliva by ELISA has been evaluated in several studies and has good sensitivity and specificity, suggesting that ELISA methods for detection of HCV antibodies in saliva can be used in epidemiological surveys [Judd et al., 2003; Chatzipantazi et al., 2004; De Cock et al., 2004]. Antibody-capture radioimmunoassay was used to measure the levels of IgG antibodies to rubella and hepatitis A viruses in the serum and saliva of edentulous, partially dentate, and dentate individuals. For both rubella and hepatitis A virus antibodies, the mean ratios between saliva and serum reactivity were similar across all three dental groups. The values for sensitivity, specificity, and positive predictive value suggest that an antiviral IgG saliva assay is a satisfactory technique, and is independent of dental health [Bagg et al., 1991]. This implies that detection of HCV-RNA in saliva is a good indicator of a type $\mathrm{C}$ hepatitis infection, in dentate or edentulous individuals.

The aim of this study was to determine if HCVRNA can be detected in saliva from anti-HCV positive patients. The correlation between presence of HCVRNA and oral pathology was studied. HCV genotypes, in the serum and saliva of the 50 anti-HCV positive patients, were confirmed by nested polymerase chain reaction (PCR).

\section{MATERIALS AND METHODS}

\section{Study Population}

The study cohort consisted of a group of 50 anti-HCV positive patients ( 38 males and 12 females), not undergoing antiviral treatment, with an average age of 46 (ranging from 26 to 60 years of age). The negative control group consisted of 25 patients (19 males and 6 females), with an average age of 38 (ranging from 22 to 55 years of age), all with non-HCV chronic liver diseases. All patients attended the Gastroenterology and Hepatology Unit of the University Hospital of Bahia, in Brazil, between January and December of 2002. The following information was recorded: age, gender, viral load, and dental care status. Both extra- and intra-oral examinations were conducted. The number of teeth present and evidence of dental caries was recorded; periodontal status was also examined. The presence of HCV-RNA was evaluated in relation to demographical, clinical, and analytical variables, using EPI-INFO 6. For statistical analysis, the Chi-square test for qualitative data and the Kruskal-Wallis test for mean analysis were used. Only when $P<0.05$ were the results considered significant.

\section{Specimen Collection}

Paired blood and saliva samples were obtained from each participant. The blood was collected in sterile tubes, and the serum was separated by centrifugation and stored at $-20^{\circ} \mathrm{C}$. Non-stimulated saliva samples were collected by spitting into a sterile falcon tube. Saliva was recovered by centrifugation and visually checked for the presence of blood cells. The cell composition of the saliva was determined by the Wright method.

\section{Detection, Genotyping, and Viral Load of HCV in Serum and Saliva}

RNA was extracted from $200 \mu \mathrm{l}$ of whole saliva and serum samples by the guanidinium isothiocyanate phenol-chloroform method [Silva et al., 2000]. The presence of HCV-RNA was determined by nested RTPCR using 5' non-coding region primers $(939,209,940$, and 211) as previously described [Davidson et al., 1995]. A selection of HCV-RNA positive RT-PCR products is presented in Figure 1.

HCV genotyping of RNA positive paired serum and saliva samples was carried out using nested PCR, as described previously [Lerat et al., 1998]. Briefly, primers 256 (5' non-coding region) and 186 NTER (core region) and $5 \mu \mathrm{l}$ of cDNA template were amplified $\left(94^{\circ} \mathrm{C}\right.$ for $1 \mathrm{~min}$, $55^{\circ} \mathrm{C}$ for $1.5 \mathrm{~min}, 72^{\circ} \mathrm{C}$ for $2 \mathrm{~min}$ ) over 40 cycles. A series of 10 internal primers were then used in a nested PCR $\left(94^{\circ} \mathrm{C}\right.$ for $1 \mathrm{~min}, 63^{\circ} \mathrm{C}$ for $1 \mathrm{~min}$, and $72^{\circ} \mathrm{C}$ for $1.5 \mathrm{~min}$ ) over 35 cycles to amplify genotype specific products. Genotype identification is based on product size as follows: $125 \mathrm{bp}$ for type 1a, $141 \mathrm{bp}$ for type 1b, $75 \mathrm{bp}$ for type 2, $87 \mathrm{bp}$ for type $3 \mathrm{a}$, and $336 \mathrm{bp}$ for type $4 \mathrm{a}$. The PCR products were separated by horizontal gel electrophoresis (metaphor $4 \%$ gel), stained with ethidium bromide, and visualized by UV transillumination. The typical band pattern for the genotypes is presented in Figure 2.

Viral load in the serum samples was determined using the Amplicor Monitor 2.0 assay (Roche Diagnostic Corp.,
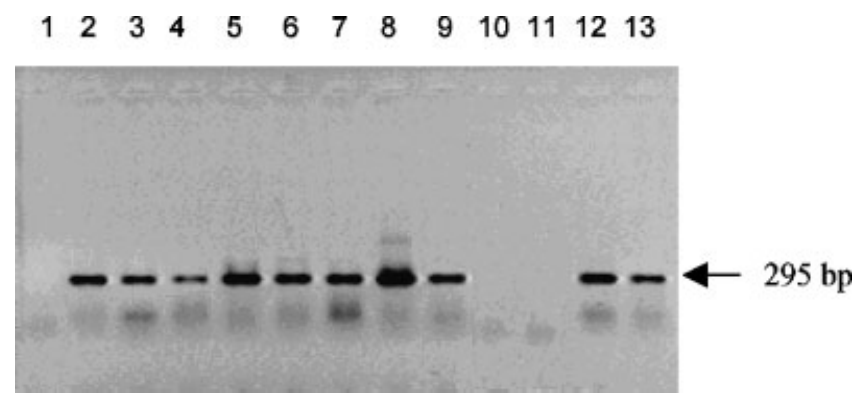

Fig. 1. Nested RT-PCR products from the paired serum and saliva samples collected from the HCV positive group. Lane $\mathbf{1}$, negative control; lanes $2,4,6$, and 8 , serum samples; lanes $3,5,7$, and $\mathbf{9}$, saliva samples; lane 10, serum negative control; lane 11, saliva negative control; lane 12, positive serum control; lane 13, saliva positive control. 


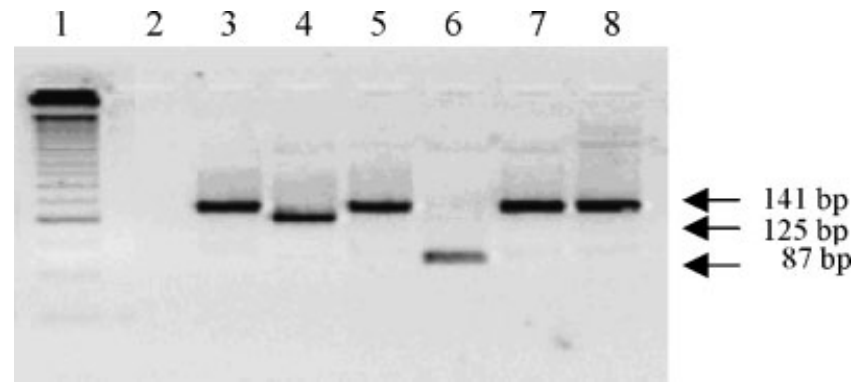

Fig. 2. Representative band pattern produced by nested PCR of the different HCV genotypes. Lane 1, 25 bp ladder; lane 2, negative control; lanes 3, 5, 7, and 8, genotype $1 \mathrm{~b}(141 \mathrm{bp})$; lane 4, genotype 1a $(125 \mathrm{bp})$; and lane 6, genotype $3 \mathrm{a}(87 \mathrm{bp})$.

Raritan, NJ), according to the manufacturer's instructions.

\section{Oral Examination}

An oral examination was performed to identify dental caries and any visible lesions of the oral mucosa. Gingival index, probing depth, and clinical attachment loss were measured by a periodontal probe, according to the Community Periodontal Index Treatment Needs (CPITN) [Coates et al., 2000].

\section{RESULTS}

HCV-RNA was detected in all of the paired serum and saliva samples from the HCV positive group (see e.g., Fig. 1). None of the samples from the negative control group were positive for HCV-RNA (data not shown)
$(P=0.01)$. This represents a diagnostic sensitivity and specificity of $100 \%$. HCV-RNA detection in saliva was found not to be dependent on the viral load in the serum. Genotype distribution among $\mathrm{HCV}$ positive patients was as follows: $64 \%$ genotype $1,34 \%$ genotype 3 , and $2 \%$ genotype 1 and 3 . Furthermore, the HCV genotypes in the paired saliva and serum samples were identical. No correlation was found between HCV-RNA in saliva, periodontal disease, and viral load (see Table I). Two of the HCV-RNA positive patients were edentulous and had no evidence of mucosal lesions.

\section{DISCUSSION}

Transmission of HCV through parenteral exposure has been well documented. However, 38\% of $\mathrm{HCV}$ positive patients do not have a history of parenteral exposure. Some studies have reported finding HCV in saliva and the possible transmission of hepatitis $\mathrm{C}$ by this route [Chen et al., 1995; Coates et al., 2000; De Cock et al., 2004]. The current study demonstrates the presence of HCV-RNA in the saliva of all patients with chronic hepatitis $\mathrm{C}$ enrolled in the study. The detection of HCV-RNA is indicative of the presence of $\mathrm{HCV}$ particles in the saliva, thus establishing saliva as a potential vehicle of infection, confirming the possibility of a non-parenteral route of transmission for HCV. Indeed, the potential to transmit $\mathrm{HCV}$ by biting has been reported in a chimpanzee model and in humans [Dusheiko et al., 1990; Abe and Inchauspe, 1991; Figueiredo et al., 1994].

In contrast to some studies [Hsu et al., 1991; Fried et al., 1992], HCV-RNA was extracted from whole saliva.

TABLE I. Periodontal Disease, Dental Status, and Viral Load of HCV Positive Patients

\begin{tabular}{|c|c|c|c|c|c|c|c|}
\hline Patient & $\begin{array}{l}\text { Periodontal } \\
\text { disease }\end{array}$ & Dental status & Viral load/ml & Patient & $\begin{array}{c}\text { Periodontal } \\
\text { disease }\end{array}$ & Dental status & Viral load/ml \\
\hline 1 & $\mathrm{P}$ & $\mathrm{PD}$ & $>8.5 \times 10^{5}$ & 26 & $\mathrm{G}$ & $\mathrm{PD}$ & $>8.5 \times 10^{5}$ \\
\hline 2 & $\mathrm{P}$ & PD & $3 \times 10^{5}$ & 27 & $\mathrm{G}$ & $\mathrm{PD}$ & $1.4 \times 10^{4}$ \\
\hline 3 & $\mathrm{P}$ & PD & $>8.5 \times 10^{5}$ & 28 & $\mathrm{H}$ & PD & $>8.5 \times 10^{5}$ \\
\hline 4 & $\mathrm{P}$ & $\mathrm{PD}$ & $7.2 \times 10^{4}$ & 29 & $\mathrm{G}$ & $\mathrm{PD}$ & $2.0 \times 10^{5}$ \\
\hline 5 & $\mathrm{G}$ & PD & $1.5 \times 10^{5}$ & 30 & $\mathrm{G}$ & $\mathrm{PD}$ & $3.4 \times 10^{5}$ \\
\hline 6 & $\mathrm{G}$ & PD & $>8.5 \times 10^{5}$ & 31 & $\mathrm{G}$ & PD & $3.7 \times 10^{5}$ \\
\hline 7 & $\mathrm{G}$ & PD & $>8.5 \times 10^{5}$ & 32 & $\mathrm{G}$ & $\mathrm{PD}$ & $1.9 \times 10^{4}$ \\
\hline 8 & $\mathrm{H}$ & ED & $1.0 \times 10^{4}$ & 33 & $\mathrm{H}$ & PD & $>8.5 \times 10^{5}$ \\
\hline 9 & $\mathrm{G}$ & PD & $1.1 \times 10^{5}$ & 34 & $\mathrm{P}$ & PD & $>8.5 \times 10^{5}$ \\
\hline 10 & $\mathrm{G}$ & $\mathrm{PD}$ & $2.5 \times 10^{5}$ & 35 & $\mathrm{P}$ & PD & $>8.5 \times 10^{5}$ \\
\hline 11 & $\mathrm{G}$ & PD & $4.4 \times 10^{5}$ & 36 & $\mathrm{G}$ & $\mathrm{PD}$ & $3.2 \times 10^{5}$ \\
\hline 12 & $\mathrm{G}$ & PD & $>8.5 \times 10^{5}$ & 37 & $\mathrm{H}$ & $\mathrm{PD}$ & $4.4 \times 10^{5}$ \\
\hline 13 & $\mathrm{P}$ & PD & $>8.5 \times 10^{5}$ & 38 & $\mathrm{G}$ & PD & $6.1 \times 10^{5}$ \\
\hline 14 & $\mathrm{G}$ & PD & $>8.5 \times 10^{5}$ & 39 & $\mathrm{G}$ & PD & $4.8 \times 10^{5}$ \\
\hline 15 & $\mathrm{H}$ & PD & $1.3 \times 10^{5}$ & 40 & $\mathrm{G}$ & PD & $3.2 \times 10^{4}$ \\
\hline 16 & $\mathrm{G}$ & $\mathrm{PD}$ & $5.5 \times 10^{4}$ & 41 & $\mathrm{P}$ & $\mathrm{PD}$ & $1.4 \times 10^{5}$ \\
\hline 17 & $\mathrm{H}$ & $\mathrm{PD}$ & $1.1 \times 10^{4}$ & 42 & $\mathrm{G}$ & $\mathrm{PD}$ & $2.2 \times 10^{5}$ \\
\hline 18 & $\mathrm{H}$ & ED & $7.2 \times 10^{5}$ & 43 & $\mathrm{G}$ & FD & $5.5 \times 10^{5}$ \\
\hline 19 & $\mathrm{H}$ & $\mathrm{PD}$ & $7.0 \times 10^{5}$ & 44 & $\mathrm{P}$ & $\mathrm{PD}$ & $2.1 \times 10^{5}$ \\
\hline 20 & G & PD & $1.8 \times 10^{4}$ & 45 & $\mathrm{H}$ & PD & $>8.5 \times 10^{5}$ \\
\hline 21 & $\mathrm{G}$ & $\mathrm{PD}$ & $1.2 \times 10^{4}$ & 46 & $\mathrm{G}$ & $\mathrm{PD}$ & $4.4 \times 10^{4}$ \\
\hline 22 & $\mathrm{G}$ & $\mathrm{PD}$ & $5.3 \times 10^{5}$ & 47 & $\mathrm{H}$ & $\mathrm{PD}$ & $7.7 \times 10^{5}$ \\
\hline 23 & $\mathrm{H}$ & PD & $6.4 \times 10^{5}$ & 48 & $\mathrm{P}$ & PD & $8.8 \times 10^{4}$ \\
\hline 24 & $\mathrm{H}$ & PD & $1.1 \times 10^{5}$ & 49 & $\mathrm{H}$ & FD & $1.7 \times 10^{5}$ \\
\hline 25 & $\mathrm{H}$ & $\mathrm{PD}$ & $5.2 \times 10^{5}$ & 50 & $\mathrm{G}$ & $\mathrm{PD}$ & $>8.5 \times 10^{5}$ \\
\hline
\end{tabular}

FD, fully dentate; PD, partially dentate; ED, edentulous; G, gingivitis; P, periodontitis; HG, healthy gums. 
The presence of HCV-RNA in some cells, especially mononuclear cells, has been described, although the presence of HCV-RNA in these cells did not correlate with the presence of HCV-RNA in the serum [Young et al., 1993]. A critical analysis of our findings and the earlier studies suggest that discrepancies in HCVRNA detection from different laboratories may relate to sample handling, differing time intervals between collection and storage, and the different RNA extraction methodologies used (whole versus cell-free saliva). A number of precautions were taken to avoid the possibility of contamination during sampling and subsequent handling. These included aliquoting all reagents, physical separation of pre-and post-PCR reactions, positive displacement pipettes, and meticulous laboratory techniques. In addition, positive and negative controls were included in all PCR assays.

The prevalence of HCV-RNA in the saliva of anti-HCV positive individuals may have important implications for dental practice. A report of extensive HCV contamination of the surrounding environment during dental surgery supports this reasoning [Piazza et al., 1995]. Moreover, sectional studies indicate that some $4 \%$ of health care workers may be anti-HCV positive [Lodi and Porter, 1996].

Disposable equipment should be used where possible, and effective sterilization of instruments and surfaces should be standard practice. Due to the expense of disposable equipment, this may be especially relevant to developing countries.

In this study, no correlation was found between periodontal disease and HCV-RNA in saliva. There is a continuous transudation of serum into the mouth through the junction of the gum margin and the tooth surface, especially associated with poor oral health. The general assumption is that HCV enters saliva by serum transudation. However, two of the patients who presented with HCV-RNA positive saliva were edentulous and had no oral lesions, suggesting that another route may allow passage of HCV from blood to the saliva. HCV detection and replication in salivary glands have been demonstrated [Biasi et al., 1995; Arrieta et al., 2001]. The possibility of direct or immune-mediated salivary aggression caused by HCV cannot be ruled out and there is evidence that HCV may be present in the salivary gland tissue. Consequently, HCV can be secreted in saliva, independent of serum transudation or blood contamination of the saliva. Although one study detected different HCV genotypes in the serum and saliva of some patients [Roy et al., 1998], no differences were seen in the present study.

In conclusion, RT-PCR is an accurate assay for the detection of HCV-RNA in saliva. Furthermore, HCVRNA detection in the saliva of HCV infected patients is independent of the viral load and oral pathology of these individuals. Saliva may, therefore, play a significant role in the non-parenteral transmission of type $\mathrm{C}$ hepatitis. The high prevalence of HCV-RNA in saliva may have serious implications in medical and dental care. However, further investigation is needed to under- stand the source of the HCV-RNA in saliva and whether it represents an increased risk of transmission.

\section{ACKNOWLEDGMENTS}

We thank Alan McBride for critical review of the manuscript. This work was supported by Grants, Fiocruz-PDTIS 254461, FINEP/PRONEX 4196086200, $\mathrm{CNPq} / \mathrm{INSERM}$ Cooperation Program, CAPES/CPOFECUB Cooperation Program, and CNPq 304713/2002-3 to M.G.R.

\section{REFERENCES}

Abe K, Inchauspe G. 1991. Transmission of hepatitis C by saliva. Lancet 337:248.

Allander T, Gruber A, Naghavi M, Beyene A, Soderstrom T, Bjorkholm M, Grillner L, Persson MA. 1995. Frequent patient-to-patient transmission of hepatitis $\mathrm{C}$ virus in a haematology ward. Lancet 345:603-607.

Alter MJ. 1996. Epidemiology of hepatitis C. Eur J Gastroenterol Hepatol 8:319-323.

Arrieta JJ, Rodriguez-Inigo E, Ortiz-Movilla N, Bartolome J, Pardo M, Manzarbeitia F, Oliva H, Macias DM, Carreno V. 2001. In situ detection of hepatitis $\mathrm{C}$ virus RNA in salivary glands. Am J Pathol 158:259-264.

Bagan JV, Ramon C, Gonzalez L, Diago M, Milian MA, Cors R, Lloria E Cardona F, Jimenez Y. 1998. Preliminary investigation of the association of oral lichen planus and hepatitis C. Oral Surg Oral Med Oral Pathol Oral Radiol Endod 85:532-536.

Bagg J, Perry KR, Parry JV, Mortimer PP, Peters TJ. 1991. The influence of dental status on the detection of IgG class anti-viral antibodies in human saliva. Arch Oral Biol 36:221-226.

Biasi D, Colombari R, Achille A, Carletto A, Caramashi P, Corrocher R, Bambara LM. 1995. HCV RNA detection in parotid gland biopsy in a patient with chronic hepatitis $\mathrm{C}$ virus liver disease. Acta Gastroenterol Belg 58:465-469.

Chatzipantazi P, Roy KM, Cameron SO, Goldberg D, Welbury R Bagg J. 2004. The feasibility and acceptability of collecting oral fluid from healthy children for anti-HCV testing. Arch Dis Child 89:185-187.

Chen M, Yun ZB, Sallberg M, Schvarcz R, Bergquist I, Berglund HB, Sonnerborg A. 1995. Detection of hepatitis C virus RNA in the cell fraction of saliva before and after oral surgery. J Med Virol 45:223226.

Coates EA, Brennan D, Logan RM, Goss AN, Scopacasa B, Spencer AJ, Gorkic E. 2000. Hepatitis C infection and associated oral health problems. Aust Dent J 45:108-114.

Davidson F, Simmonds P, Ferguson JC, Jarvis LM, Dow BC, Follett EA, Seed CR, Krusius T, Lin C, Medgyesi GA. 1995. Survey of major genotypes and subtypes of hepatitis $\mathrm{C}$ virus using RFLP of sequences amplified from the $5^{\prime}$ non-coding region. J Gen Virol 76:1197-1204.

De Cock L, Hutse V, Verhaegen E, Quoilin S, Vandenberghe H, Vranckx R. 2004. Detection of HCV antibodies in oral fluid. J Virol Methods 122:179-183.

Dusheiko GM, Smith M, Scheuer PJ. 1990. Hepatitis C virus transmitted by human bite. Lancet 336:503-504.

Figueiredo JF, Borges AS, Martinez R, Martinelli Ade L, Villanova MG, Covas DT, Passas AD. 1994. Transmission of hepatitis $\mathrm{C}$ virus but not human immunodeficiency virus type 1 by a human bite. Clin Infect Dis 19:546-547.

Fried MW, Shindo M, Fong TL, Fox PC, Hoofnagle JH, Di Bisceglie AM. 1992. Absence of hepatitis C viral RNA from saliva and semen of patients with chronic hepatitis C. Gastroenterology 102:13061308.

Haddad J, Deny P, Munz-Gotheil C, Ambrosini JC, Trinchet JC Pateron D, Mal F, Callard P, Beaugrand M. 1992. Lymphocytic sialadenitis of Sjogren's syndrome associated with chronic hepatitis C virus liver disease. Lancet 339:321-323.

Hsu HH, Wright TL, Luba D, Martin M, Feinstone SM, Garcia G, Greenberg HB. 1991. Failure to detect hepatitis C virus genome in human secretions with the polymerase chain reaction. Hepatology 14:763-767. 
Jorgensen C, Legouffe MC, Perney P, Coste J, Tissot B, Segarra C Bologna C, Bourrat L, Combe B, Blanc F, Sany J. 1996. Sicca syndrome associated with hepatitis $\mathrm{C}$ virus infection. Arthritis Rheum 39:1166-1171.

Judd A, Parry J, Hickman M, McDonald T, Jordan L, Lewis K, Contreras M, Dusheiko G, Foster G, Gill N, Kemp K, Main J, Murray-Lyon I, Nelson M. 2003. Evaluation of a modified commercial assay in detecting antibody to hepatitis $\mathrm{C}$ virus in oral fluids and dried blood spots. J Med Virol 71:49-55.

Lerat H, Rumin S, Habersetzer F, Berby F, Trabaud MA, Trepo C, Inchauspe G. 1998. In vivo tropism of hepatitis C virus genomic sequences in hematopoietic cells: Influence of viral load, viral genotype, and cell phenotype. Blood 91:3841-3849.

Lodi G, Porter SR. 1996. Occupational risk of hepatitis C virus infection to dental health care staff: An update. Dent Update 23:255-258.

Maticic M, Poljak M, Kramar B, Seme K, Brinovec V, Meglic-Volkar J, Zakotnik B, Skaleric U. 2001. Detection of hepatitis C virus RNA from gingival crevicular fluid and its relation to virus presence in saliva. J Periodontol 72:11-16.

Nagao Y, Sata M, Tanikawa K, Itoh K, Kameyama T. 1995. Lichen planus and hepatitis $\mathrm{C}$ virus in the northern Kyushu region of Japan. Eur J Clin Invest 25:910-914.
Piazza M, Borgia G, Picciotto L, Nappa S, Cicciarello S, Orlando R. 1995. Detection of hepatitis $\mathrm{C}$ virus-RNA by polymerase chain reaction in dental surgeries. J Med Virol 45:40-42.

Roy KM, Bagg J, McCarron B, Good T, Cameron S, Pithie A. 1998 Predominance of HCV type 2a in saliva from intravenous drug users. J Med Virol 54:271-275.

Silva LK, Parana R, Souza SP, Berby F, Kay A, Trepo C, Santana N, Cotrim H, Lyra LG, Reis MG. 2000. Hepatitis C virus genotypes in a northeastern area of Brazil. Am J Trop Med Hyg 62:257260.

Tucker SC, Coulson IH. 1999. Lichen planus is not associated with hepatitis $\mathrm{C}$ virus infection in patients from north west England Acta Derm Venereol 79:378-379.

Young KC, Chang TT, Liou TC, Wu HL. 1993. Detection of hepatitis C virus RNA in peripheral blood mononuclear cells and in saliva. J Med Virol 41:55-60.

Zekry A, Whiting P, Crawford DH, Angus PW, Jeffrey GP, Padbury RT, Gane EJ, McCaughan GW. 2003. Liver transplantation for HCVassociated liver cirrhosis: predictors of outcomes in a population with significant genotype 3 and 4 distribution. Liver Transpl 9:339_ 347. 